\title{
Scientific Analysis of Iron Making By-Products Excavated from Gogi-ri, Namwon, Korea
}

\author{
Chae Rin Bae', In Cheol Kwon², Nam Chul Cho, \\ ${ }^{1}$ Department of Cultural Heritage Conservation Science, Kongju National University, Gongju 32588, Korea \\ ${ }^{2}$ National Museum of Modern and Contemporary Art, Gwacheon 13829, Korea
}

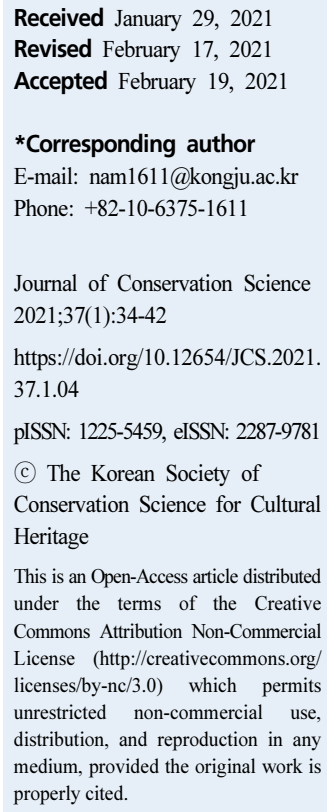

ABSTRACT This study analyzes six slags excavated from the iron making site in Gogi-ri, Namwon, Korea to understand the characteristics of the ruins, and to confirm the iron making process performed at the time. The chemical components of the iron making by-products from the Gogi-ri site were analyzed, and the findings indicate total $\mathrm{Fe}$ contents between $23.24 \%$ and $37.56 \%$, which are lower than the typical total $\mathrm{Fe}$ content found in ancient iron making processes. The deoxidation agent contents of the slags ranged from $43.88 \%$ to $58.13 \%$, which are higher than the typical deoxidation agent content of ancient iron making processes. The high content suggests smooth separation between iron and slags, and $\mathrm{TiO}_{2}$ detected from the site suggests the use of materials with high titanium content in the iron making in the region. As for the microstructures of the slags, some slags have long pillar-shaped fayalites, while others have pillar-shaped wüstite along with ulvöspinel. Slags from the forging furnace show hammer scales created by both the earlier stages and later stages of forging work. The findings suggest that the iron making site in Gogi-ri, Namwon, Korea used to be an iron making facility where a full range of iron making process was carried out ranging from smelting to forging, and the ironmakers used a wide array of technologies to manufacture iron products.

Key Words Slag, Iron making, Smelting, Forging

\section{INTRODUCTION}

In the ancient times, the iron making technology was a crucial technological element that could determine a state's growth. For ancient states where advancements in the metal culture had significant impact on their fate, the use of metallurgy techniques such as mining, smelting, molding, forging, and gilding to manufacture metal products held great significance. A state's level of advancements in metallurgy serves as an indicator of its growth.

Metallurgical analyses are performed on excavated artifacts to understand ancient iron making technologies. However, given the fact that iron corrodes easily, it is difficult to understand the development of the iron culture by solely relying on iron artifacts (Lee, 2010).

This issue can be circumvented by analyzing iron making by-products instead. Slags mean residues created by smelting or processing iron (Yoon, 1986). Iron ores and slags are excavated in large quantities from iron making sites. When analyzed, smelting slags from metallurgy sites provide ample information required to understand the properties of the slags, estimate the works performed at the site, and determine the level of advancements in smelting technologies (Rho, 2000).

Slags contain materials from raw ores, furnace walls and mixtures, along with a significant amount of iron oxide. These materials are traces of the works performed at the time. 
Ancient iron making processes can be estimated by using raw materials used for iron making and fuels used to melt iron. Thus, slags provide significant insights into the iron making process in the ancient times.

This study analyzes slags excavated from an iron making site in Gogi-ri, Namwon, Korea, to understand the iron making process carried out at the site.

\section{SITE OVERVIEW}

The Gogi-ri site was excavated and investigated by the Jeonju Research Institute for Cultural Heritage under the authorization of the Korean Cultural Heritage Administration. Artifacts excavated from the site provide an insight into the full cycle of iron making process from smelting to forging.

Structures excavated at the site include an smelting furnace, a forging furnace, drainage facilities, unidentified structures, and a disposal area. The rectangular smelting furnace is heavily damaged. However, a part of the lower stone pillar remains, along with a tap and a hole used to collect slags. The forging furnace has a flat and round shape, and the furnace walls at the bottom and the sides are between 2 and 3 centimeters thick. Hammer scales, granular slags, and small iron ores were found inside the furnace. Objects excavated from the site include white porcelain and earthenware pieces, forging tools including hammers and pliers, large quantities of furnace bottom slags, leaked slags, and furnace wall fragments.

The Gogi-ri site is the first iron making site in the mountainous areas in the eastern part of Jeollabuk-do containing evidence on the full cycle of iron making processes from smelting to forging. The excavated artifacts puts the operation of the site in or around the 18th century (Jeonju Research Institute for Cultural Heritage, 2016).

\section{ANALYZED SAMPLES AND ANALYSIS METHODS}

\subsection{Analyzed samples}

This study analyzed slags excavated from the iron making site in Gogi-ri, Namwon, Korea (Figure 1, Table 1). NG-1

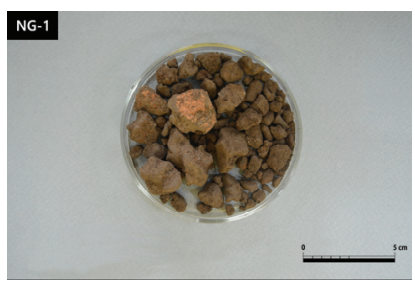

NG-4
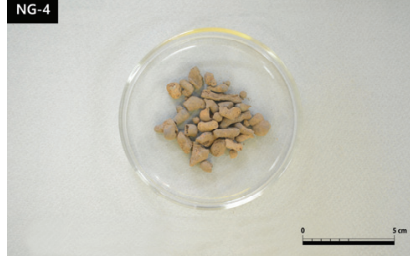

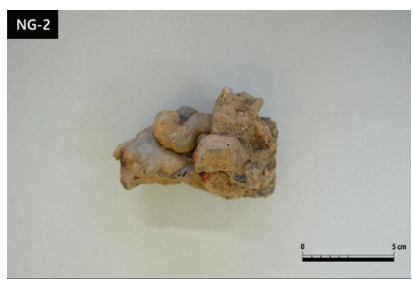

NG-5

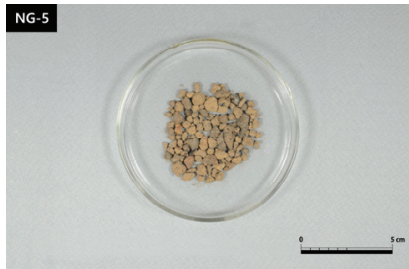

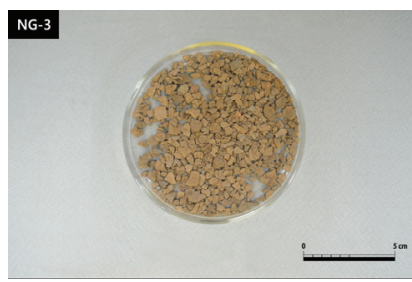

NG-6

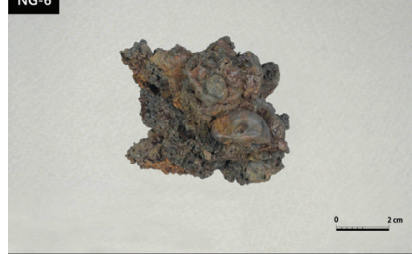

Figure 1. Slags excavated from Gogi-ri site, Namwon.

Table 1. Characteristics of slags excavated from Gogi-ri site, Namwon

\begin{tabular}{cccc}
\hline No. & Name & Findspot & Characteristic \\
\hline NG-1 & Slag & smelting furnace & Relatively light in weight, weaker magnetism \\
\hline NG-2 & Leaked slag & smelting furnace & Shows trails of flowing down \\
\hline NG-3 & Hammer scales & forging furnace & Split into plates, and a slight gloss on the side \\
\hline NG-4 & granular slags & forging furnace & Solidified into a spherical shape \\
\hline NG-5 & granular slags & Unidentified Structures & Solidified into a spherical shape \\
\hline NG-6 & Slag & Unknown & Porous and breaks easily \\
\hline
\end{tabular}


and NG-2 were found in the smelting furnace. NG-3 and NG-4 were excavated from the forging furnace, and NG-5 was recovered from the unidentified structures. The spot where NG-6 was found is unknown. A naked eye observation revealed traces of melting and hardening in NG-1. The material is also relatively light and weak in magnetism. The shape of NG-2 suggests that the molten slag leaked from the furnace before hardening. NG-3 consists of hammer scales in thin tabular shapes, and the cross sections have slight luster. NG-4 and NG-5 are granular slags created by the hardening of molten slags into spherical shapes. NG-6 is a fragile porous slag.

\subsection{Analysis methods}

\subsubsection{Principal component analysis}

Samples were cleaned and completely dried for an analysis of their principal components using wavelength dispersive x-ray fluorescence spectroscopy (WD-XRF, S4 Pioneer, Bruker, DEU). Principal component analysis was not performed on NG-3, NG-4, and NG-5, as samples could not be obtained in the amounts required for the analysis. The other slag samples were pre-processed for glassification, and the findings were quantitatively measured.

\subsubsection{Observation of microstructures}

The samples were mounted using epoxy resin. The mounted samples were gradually polished from 220 mesh to 4,000 mesh, followed by fine polishing with $3 \mu \mathrm{m}$ and $1 \mu \mathrm{m}$ DP-sprays (Struers, DEU) to remove all scratches from the samples. The polished samples were observed using a metallographic microscope (DM 2500M, Leica, DEU). The details of the microstructures were observed using a scanning electron microscope (SEM, MIRA3, TESCAN, CZE), and their chemical composition was analyzed using an energy dispersive spectrometer (EDS, QUANTA300, BRUNKER, $\mathrm{DEU})$. The samples were coated with platinum $(\mathrm{Pt})$ to increase their conductivity and minimize the impact on composition ratios.

\section{FINDINGS}

\subsection{Principal component analysis}

Table 2 summarizes the findings of the XRF analysis on the principal components of the slags excavated from the Gogi-ri site.

Total Fe content, or $\mathrm{T} \cdot \mathrm{Fe}$, refers the content of iron remaining in a slag. The iron content allows for estimation of the recovery rate of iron from raw materials. A low total Fe content indicates a higher recovery rate by smelting. The typical total $\mathrm{Fe}$ content of slags created by ancient smelting ranges between $30 \%$ and 50\% (Yoon, 1986).

The deoxidation agent improves the liquidity of slags, thereby facilitating the separation between slags and metal iron. It also lowers the melting temperature for easier iron manufacture. The typical deoxidation agent $\left(\mathrm{SiO}_{2}+\mathrm{Al}_{2} \mathrm{O}_{3}+\right.$ $\mathrm{CaO}+\mathrm{MgO}$ ) content of ancient iron manufacture ranges between $17 \%$ and $40 \%$ (Yoon, 1986). A higher deoxidation agent content suggests smoother separation of metal iron.

The findings of the principal component analysis can be summarized as follows. The $\mathrm{T} \cdot \mathrm{Fe}$ of NG-1 was $34.48 \%$, with $\mathrm{FeO}$ at $44.36 \mathrm{wt} \%, \mathrm{SiO}_{2}$ at $28.24 \mathrm{wt} \%, \mathrm{Al}_{2} \mathrm{O}_{3}$ at 8.79 $\mathrm{wt} \%, \mathrm{CaO}$ at $5.84 \mathrm{wt} \%$, and $\mathrm{MgO}$ at $1.01 \mathrm{wt} \%$, which confirms that NG-1 is slag created by iron manufacture process. The deoxidation agent $\left(\mathrm{SiO}_{2}+\mathrm{Al}_{2} \mathrm{O}_{3}+\mathrm{CaO}+\mathrm{MgO}\right)$ content was high at $43.88 \%$. $\mathrm{TiO}_{2}$ measured at $6.46 \mathrm{wt} \%$, and $\mathrm{V}_{2} \mathrm{O}_{5}$ at $0.47 \mathrm{wt} \%$. The finding suggests the use of raw materials with high titanium content.

The $\mathrm{T} \cdot \mathrm{Fe}$ of NG-2 was $23.24 \%$, with $\mathrm{FeO}$ at $29.90 \mathrm{wt} \%$ $\mathrm{SiO}_{2}$ at $42.15 \mathrm{wt} \%, \mathrm{Al}_{2} \mathrm{O}_{3}$ at $12.50 \mathrm{wt} \%, \mathrm{CaO}$ at $2.68 \mathrm{wt} \%$, and $\mathrm{MgO}$ at $0.80 \mathrm{wt} \%$, which confirms that $\mathrm{NG}-2$ is slag created by iron manufacture process. The deoxidation agent $\left(\mathrm{SiO}_{2}+\mathrm{Al}_{2} \mathrm{O}_{3}+\mathrm{CaO}+\mathrm{MgO}\right)$ content was high at $58.13 \%$. $\mathrm{TiO}_{2}$ measured at $1.59 \mathrm{wt} \%$. The finding suggests the use of raw materials with high titanium content.

Table 2. Chemical composition of slags from Gogi-ri site, Namwon

\begin{tabular}{|c|c|c|c|c|c|c|c|c|c|c|c|c|c|c|c|c|c|c|}
\hline \multirow{2}{*}{ No. } & \multicolumn{16}{|c|}{ Major composition (wt\%) } & \multirow{2}{*}{$\mathbf{F e}$} & \multirow{2}{*}{$\begin{array}{c}\text { Deoxi-dation } \\
\text { agent }\end{array}$} \\
\hline & $\mathrm{FeO}$ & $\mathrm{SiO}_{2}$ & $\mathrm{Al}_{2} \mathrm{O}_{3}$ & $\mathrm{TiO}_{2}$ & $\mathrm{CaO}$ & $\mathrm{K}_{2} \mathrm{O}$ & MgO & $\mathrm{ZrO}_{2}$ & $\mathrm{MnO}$ & $\mathrm{Na}_{2} \mathrm{O}$ & $\mathrm{P}_{2} \mathrm{O}_{5}$ & $\mathrm{~V}_{2} \mathrm{O}_{5}$ & $\mathrm{SO}_{3}$ & SrO & $\mathbf{R b}_{2} \mathbf{O}$ & $\mathrm{CuO}$ & & \\
\hline NG-1 & 44.36 & 28.24 & 8.79 & 6.46 & 5.84 & 2.70 & 1.01 & 0.57 & 0.56 & 0.48 & 0.47 & 0.39 & 0.08 & 0.04 & 0.01 & - & 34.48 & 43.88 \\
\hline NG-2 & 29.90 & 42.15 & 12.50 & 1.59 & 2.68 & 8.73 & 0.80 & 0.24 & 0.20 & 0.42 & 0.62 & - & 0.13 & 0.02 & 0.04 & 0.03 & 23.24 & 58.13 \\
\hline NG-6 & 48.32 & 30.34 & 8.64 & 2.02 & 5.37 & 2.22 & 1.19 & 0.21 & 0.25 & 0.71 & 0.33 & 0.33 & 0.04 & 0.03 & 0.01 & - & 37.56 & 45.54 \\
\hline
\end{tabular}


The $\mathrm{T} \cdot \mathrm{Fe}$ of NG-6 was $37.56 \%$, with $\mathrm{FeO}$ at $48.32 \mathrm{wt} \%$ $\mathrm{SiO}_{2}$ at $30.34 \mathrm{wt} \%, \mathrm{Al}_{2} \mathrm{O}_{3}$ at $8.64 \mathrm{wt} \%, \mathrm{CaO}$ at $5.37 \mathrm{wt} \%$, and $\mathrm{MgO}$ at $1.19 \mathrm{wt} \%$, which confirms that NG-6 is slag created by iron manufacture process. The deoxidation agent $\left(\mathrm{SiO}_{2}+\mathrm{Al}_{2} \mathrm{O}_{3}+\mathrm{CaO}+\mathrm{MgO}\right)$ content was high at $45.54 \%$. $\mathrm{TiO}_{2}$ measured at $2.02 \mathrm{wt} \%$, and $\mathrm{V}_{2} \mathrm{O}_{5}$ at $0.33 \mathrm{wt} \%$. The finding suggests the use of raw materials with high titanium content.

\subsection{Observation of microstructures}

\subsubsection{Slag (NG-1)}

Figure 2A shows the findings of the observation of NG-1 microstructures. Fine wüstite and coarse Wüstite were found on the glass phase, along with white polygonal particles. In order to examine the details of the microstructure and its chemical composition, the inner structure of the slag was magnified and observed using the SEM (Figure 2B), followed by an EDS analysis. The findings are listed in Table 3. The SEM-EDS analysis found a high $\mathrm{FeO}$ content in 1-01, confirming the material as wüstite. The fine wüstite was forming a tree shape. The white polygonal structures in 1-02 and 1-03 were high in $\mathrm{FeO}$ and $\mathrm{TiO}_{2}$, which indicates that the materials are ulvöspinel. 1-04 had lower FeO content and higher $\mathrm{SiO}_{2}, \mathrm{Al}_{2} \mathrm{O}_{3}, \mathrm{CaO}$ contents, confirming the material as glass phase.

\subsubsection{Leaked slag (NG-2)}

Figure $3 \mathrm{~A}$ shows the findings of the observation of NG-2 microstructures. Long pillar-shaped fayalite and white polygonal and tree-shaped structures were observed on the glass phase. In order to examine the details of the microstructure and its chemical composition, the inner structure of the slag was magnified and observed using the SEM (Figure 3B), followed by an EDS analysis. The findings are listed in Table 4. The SEM-EDS analysis found high $\mathrm{FeO}$ and $\mathrm{TiO}_{2}$ content in 2-01, which indicates that the material is ulvöspinel. 2-02 had high $\mathrm{FeO}$ content above 99\%, which suggests that iron particles remaining in the furnace after smelting may have been mixed in the leaked material. The high content of $\mathrm{FeO}$ and $\mathrm{SiO}_{2}$ in 2-03 shows that the material is fayalite. 2-04 had lower $\mathrm{FeO}$ content and higher $\mathrm{SiO}_{2}$ and $\mathrm{Al}_{2} \mathrm{O}_{3}$, contents, confirming the material as glass phase. 2-05 had higher $\mathrm{FeO}$ and $\mathrm{CaO}$ content than 2-04, as well as high $\mathrm{SiO}_{2}$ and $\mathrm{Al}_{2} \mathrm{O}_{3}$, contents. The findings suggest glass phase with high $\mathrm{FeO}$ and $\mathrm{CaO}$ content.

Table 3. EDS analysis results of NG-1 slag

\begin{tabular}{|c|c|c|c|c|c|c|c|c|}
\hline \multirow{2}{*}{$\begin{array}{l}\text { Spec- } \\
\text { trum }\end{array}$} & \multicolumn{8}{|c|}{ Composition (wt\%) } \\
\hline & $\mathrm{FeO}$ & $\mathrm{TiO}_{2}$ & $\mathrm{SiO}_{2}$ & $\mathrm{CaO}$ & $\mathrm{Al}_{2} \mathrm{O}_{3}$ & MgO & $\mathrm{K}_{2} \mathrm{O}$ & $\mathrm{V}_{2} \mathrm{O}_{5}$ \\
\hline $1-01$ & 93.72 & 2.36 & 1.66 & 0.46 & 0.87 & 0.67 & 0.26 & - \\
\hline $1-02$ & 64.05 & 3.44 & 15.26 & 5.45 & 8.67 & 1.23 & 1.09 & 0.82 \\
\hline $1-03$ & 69.42 & 3.67 & 11.36 & 5.33 & 7.44 & 0.68 & 0.95 & 1.15 \\
\hline 1-04 & 39.88 & - & 34.39 & 13.53 & 8.19 & 1.01 & 3.00 & - \\
\hline
\end{tabular}
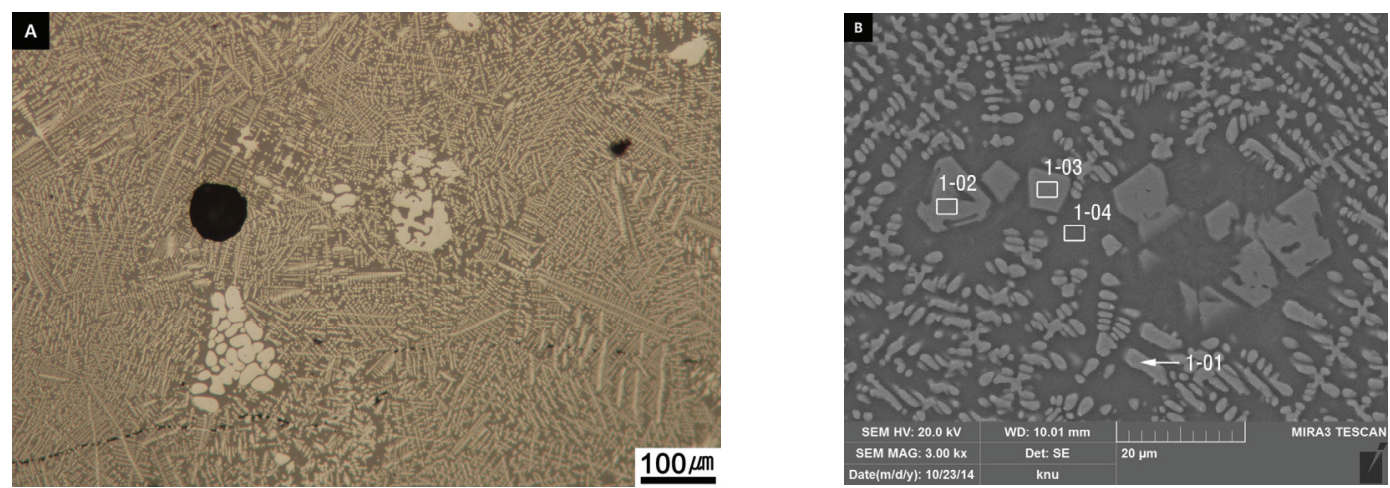

Figure 2. Microstructure of NG-1 slag; (A) Image of metallurgical microscope, (B) SEM image and point of EDS analysis. 

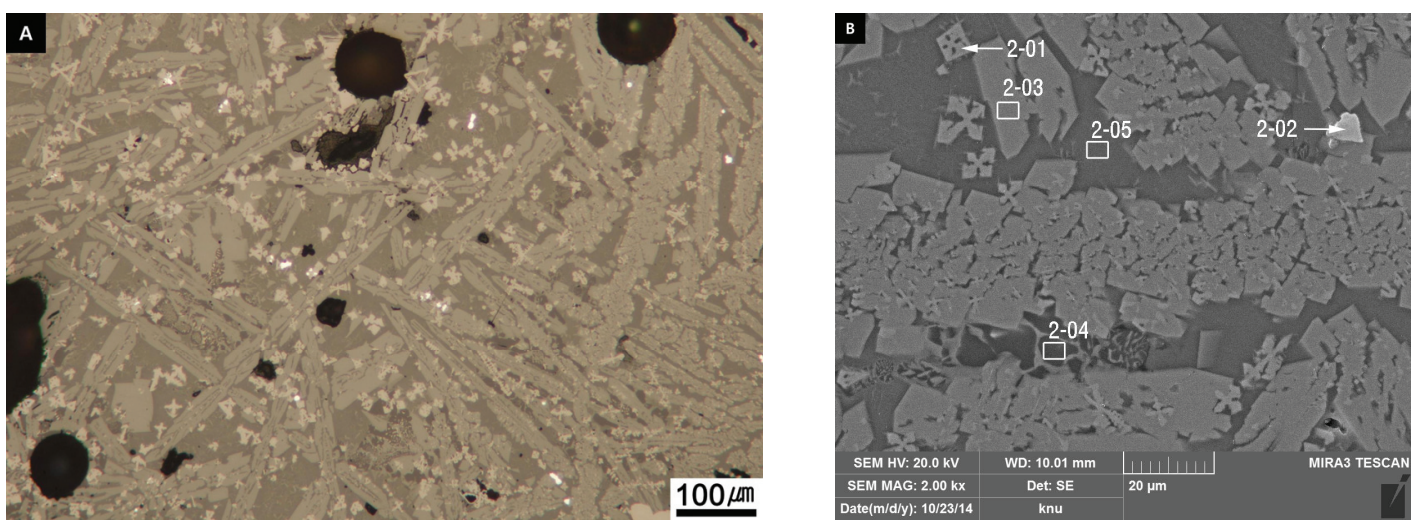

Figure 3. Microstructure of NG-2 slag; (A) Image of metallurgical microscope, (B) SEM image and point of EDS analysis.

Table 4. EDS analysis results of NG-2 slag

\begin{tabular}{ccccccccccc}
\hline \multirow{2}{*}{$\begin{array}{c}\text { Spec- } \\
\text { trum }\end{array}$} & $\mathbf{F e O}$ & $\mathbf{T i O}_{2}$ & $\mathbf{S i O}_{2}$ & $\mathbf{C a O}$ & $\mathbf{A l}_{\mathbf{2}} \mathbf{O}_{3}$ & $\mathbf{M g O}$ & $\mathbf{K}_{\mathbf{2}} \mathbf{O}$ & $\mathbf{V}_{\mathbf{2}} \mathbf{O}_{\mathbf{5}}$ & $\mathbf{M n O}$ & $\mathbf{N a}_{2} \mathbf{O}$ \\
\hline $\mathbf{2 - 0 1}$ & 64.28 & 24.65 & 1.02 & 0.51 & 7.07 & - & - & 2.48 & - & - \\
\hline $\mathbf{2 - 0 2}$ & 99.40 & - & 0.33 & 0.26 & - & - & - & - & - & - \\
\hline $\mathbf{2 - 0 3}$ & 66.36 & 3.54 & 19.45 & 3.55 & 4.44 & 0.53 & 1.05 & 0.10 & 0.98 & - \\
\hline $\mathbf{2 - 0 4}$ & 10.34 & - & 46.07 & 3.42 & 22.08 & - & 18.10 & - & - & - \\
\hline $\mathbf{2 - 0 5}$ & 24.16 & 0.94 & 35.73 & 15.53 & 16.08 & - & 5.56 & - & - & 1.99 \\
\hline
\end{tabular}
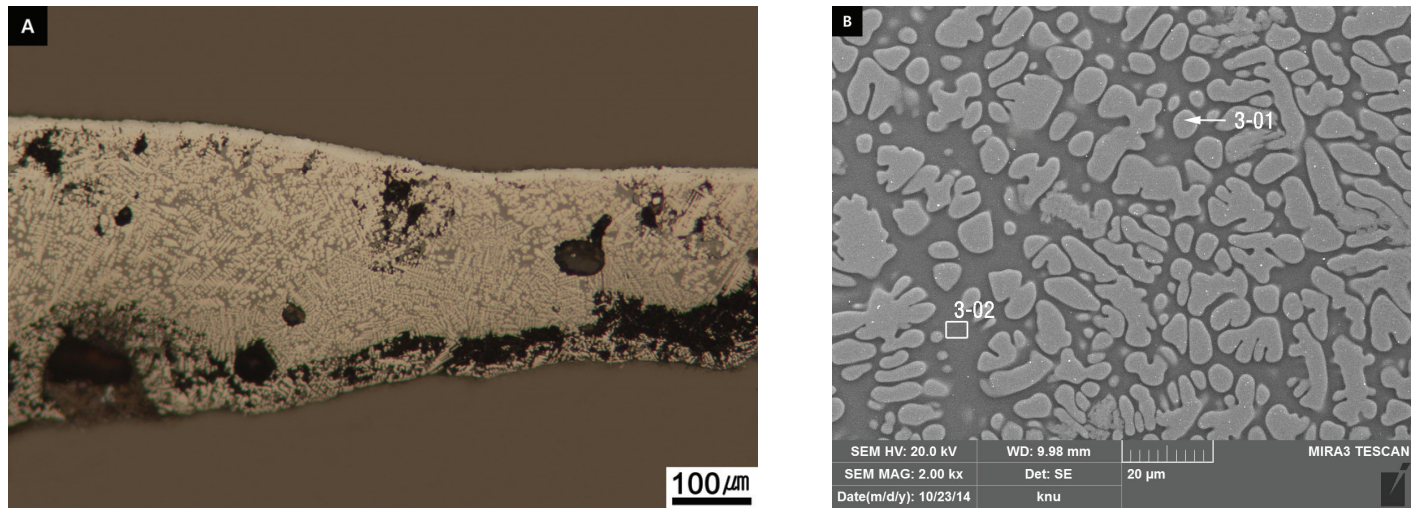

Figure 4. Microstructure of NG-3a slag; (A) Image of metallurgical microscope, (B) SEM image and point of EDS analysis.

\subsubsection{Hammer scales (NG-3)}

Figures $4 \mathrm{~A}$ and $5 \mathrm{~A}$ shows the findings of the observation of NG-3 hammer scales. Some hammer scales have leaf-like shaped wüstite on glass phase (NG-3a), and others have flat, agglomerated wüstite (NG-3b). In order to examine the details of the microstructure and its chemical composition, the inner structure of the slag was magnified and observed using the SEM (Figures $4 \mathrm{~B}$ and $5 \mathrm{~B}$ ), followed by an EDS analysis. The findings are listed in Table 5. The SEM-EDS analysis showed high $\mathrm{FeO}$ contents in 3-01 and 3-04, which confirms the material as wüstite. The lower $\mathrm{FeO}$ content in 3-01 than 3-04 seems to have been caused by the surrounding glass phase. Given their shape and the high $\mathrm{SiO}_{2}, \mathrm{Al}_{2} \mathrm{O}_{3}, \mathrm{CaO}$ contents, 3-02 and 3-03 seem to be glass phase. The high FeO content seems to have been caused by the surrounding wüstite. 

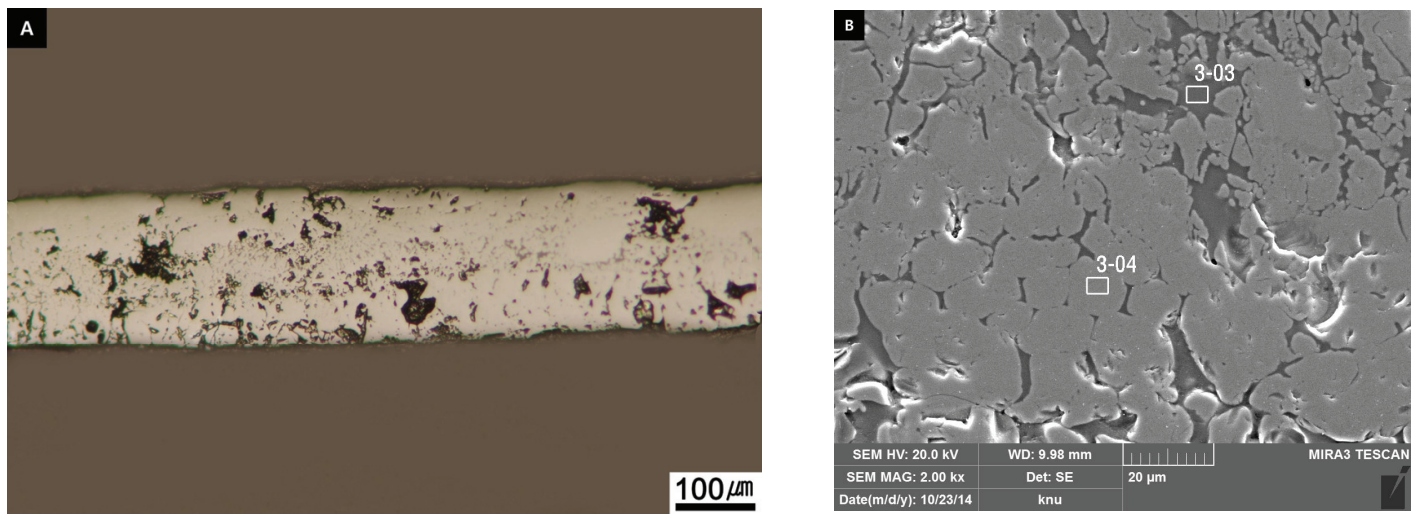

Figure 5. Microstructure of NG-3b slag; (A) Image of metallurgical microscope, (B) SEM image. and point of EDS analysis.

Table 5. EDS analysis results of NG-3a, b slag

\begin{tabular}{ccccccccc}
\hline \multirow{2}{*}{$\begin{array}{c}\text { Spec- } \\
\text { trum }\end{array}$} & $\mathbf{7 e O}$ & $\mathrm{TiO}_{2}$ & $\mathbf{S i O}_{2}$ & $\mathbf{C a O}$ & $\mathbf{A l}_{2} \mathbf{O}_{3}$ & $\mathbf{M g O}$ & $\mathbf{K}_{2} \mathbf{O}$ & $\mathbf{V}_{2} \mathbf{O}_{\mathbf{5}}$ \\
\hline $3-01$ & 77.63 & 3.57 & 10.14 & 3.03 & 3.30 & 0.73 & 1.01 & 0.59 \\
\hline $3-02$ & 51.33 & 2.40 & 26.22 & 10.78 & 5.90 & 0.41 & 2.96 & - \\
\hline $3-03$ & 56.37 & - & 23.26 & 12.83 & 3.90 & - & 3.65 & - \\
\hline $3-04$ & 99.52 & 0.48 & - & - & - & - & - & - \\
\hline
\end{tabular}
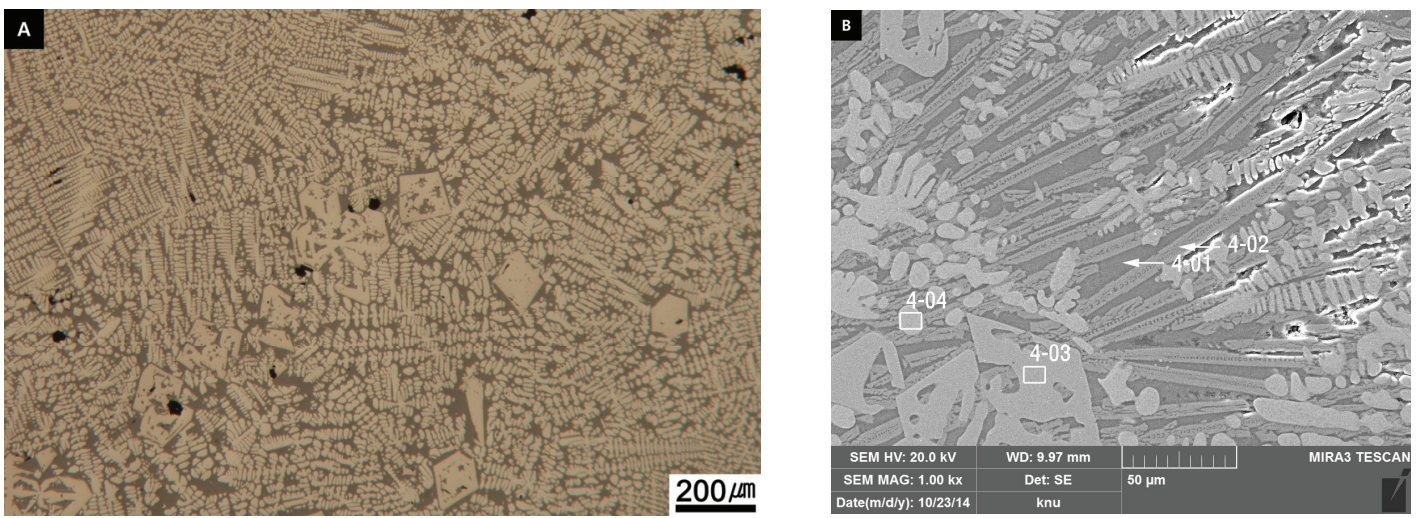

Figure 6. Microstructure of NG-4 slag; (A) Image of merallurgical microscope, (B) SEM image and point of EDS analysis.

\subsubsection{Granular slags (NG-4)}

Figure 6A shows the findings of the observation of NG-4 microstructures. Long pillar-shaped fayalite were observed on the glass phase, along with tree-shaped wüstite and white polygonal structures. In order to examine the details of the microstructure and its chemical composition, the inner structure of the slag was magnified and observed using the SEM (Figure 6B), followed by an EDS analysis. The findings are listed in Table 6. According to the SEM-EDS analysis results, 1-04 had lower $\mathrm{FeO}$ content and higher $\mathrm{SiO}_{2}, \mathrm{Al}_{2} \mathrm{O}_{3}$, $\mathrm{CaO}$ contents, confirming the material as glass phase. 4-02 was confirmed as fayalite based on the high $\mathrm{FeO}$ and $\mathrm{SiO}_{2}$ contents. The high $\mathrm{FeO}$ and $\mathrm{TiO}_{2}$ content in 4-03 indicates that the material is ulvöspinel. 4-04 had high $\mathrm{FeO}$ content, which confirms the material as wüstite. The microstructure and component analyses indicate wüstite grows larger and exist in greater quantities than smelting slags. 
Table 6. EDS analysis results of NG-4 slag

\begin{tabular}{|c|c|c|c|c|c|c|c|c|c|}
\hline \multirow{2}{*}{$\begin{array}{l}\text { Spec- } \\
\text { trum }\end{array}$} & \multicolumn{9}{|c|}{ Composition (wt\%) } \\
\hline & $\mathrm{FeO}$ & $\mathrm{TiO}_{2}$ & $\mathrm{SiO}_{2}$ & $\mathrm{CaO}$ & $\mathrm{Al}_{2} \mathrm{O}_{3}$ & MgO & $\mathrm{K}_{2} \mathrm{O}$ & $\mathrm{V}_{2} \mathrm{O}_{5}$ & $\mathrm{Na}_{2} \mathrm{O}$ \\
\hline 4-01 & 28.20 & 1.44 & 37.18 & 13.31 & 11.62 & - & 7.25 & - & 0.99 \\
\hline 4-02 & 51.74 & 1.06 & 30.85 & 6.23 & 5.58 & 1.19 & 3.35 & - & - \\
\hline 4-03 & 80.63 & 3.94 & 8.55 & 1.05 & 3.65 & 0.83 & 0.35 & 1.01 & - \\
\hline 4-04 & 78.91 & 1.08 & 13.97 & 2.89 & 1.62 & 0.50 & 1.02 & - & - \\
\hline
\end{tabular}
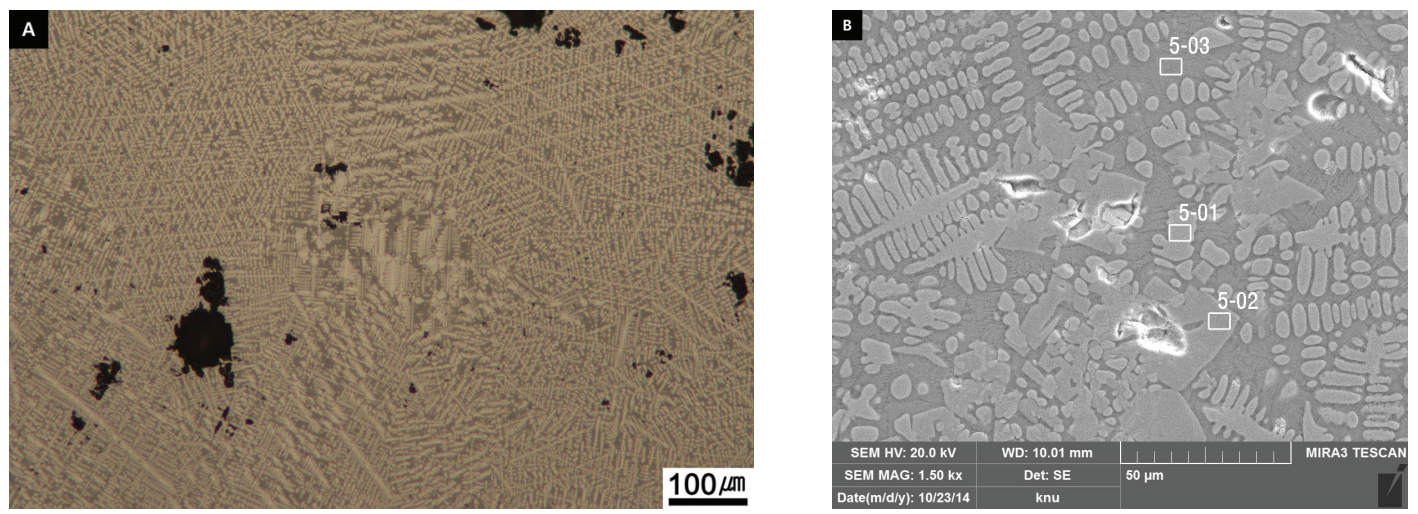

Figure 7. Microstructure of NG-5 slag; (A) Image of merallurgical microscope, (B) SEM image and point of EDS analysis.

Table 7. EDS analysis results of NG-5 slag

\begin{tabular}{|c|c|c|c|c|c|c|c|c|}
\hline \multirow{2}{*}{$\begin{array}{l}\text { Spec- } \\
\text { trum }\end{array}$} & \multicolumn{8}{|c|}{ Composition (wt\%) } \\
\hline & $\mathrm{FeO}$ & $\mathrm{TiO}_{2}$ & $\mathrm{SiO}_{2}$ & $\mathrm{CaO}$ & $\mathrm{Al}_{2} \mathrm{O}_{3}$ & MgO & $\mathrm{K}_{2} \mathrm{O}$ & $\mathrm{V}_{2} \mathrm{O}_{5}$ \\
\hline $5-01$ & 74.59 & 3.05 & 12.83 & 4.62 & 3.00 & 0.77 & 1.14 & - \\
\hline $5-02$ & 67.96 & 22.10 & 2.70 & 0.62 & 4.94 & - & - & 1.69 \\
\hline 5-03 & 57.30 & 1.93 & 24.85 & 7.54 & 4.66 & 0.93 & 2.79 & - \\
\hline
\end{tabular}

\subsubsection{Granular slags (NG-5)}

Figure 7A shows the findings of the observation of NG-5 microstructures. Leaf-like shaped wüstite were observed on the glass phase, along with white polygonal structures. In order to examine the details of the microstructure and its chemical composition, the inner structure of the slag was magnified and observed using the SEM (Figure 7B), followed by an EDS analysis. The findings are listed in Table 7. The SEM-EDS analysis found high $\mathrm{FeO}$ content in 5-01, which indicates that the material is wüstite. 5-02 had high $\mathrm{FeO}$ and $\mathrm{TiO}_{2}$ contents, confirming the material as ulvöspinel. The metallurgy microscope observation suggested that 5-03 may be glass phase. However, the component analysis found high $\mathrm{FeO}$ and $\mathrm{SiO}_{2}$ contents, confirming the material as fayalite.

\subsubsection{Slag (NG-6)}

Figure $8 \mathrm{~A}$ shows the findings of the observation of NG-6 microstructures. Long pillar-shaped fayalite and white polygonal and tree-shaped structures were observed on the glass phase, along with iron particles that remained in the furnace after smelting. In order to examine the details of the microstructure and its chemical composition, the inner structure of the slag was magnified and observed using the SEM (Figure 8B), followed by an EDS analysis. The findings are listed in Table 8. The low content of $\mathrm{FeO}$ and the high $\mathrm{SiO}_{2}$ and $\mathrm{Al}_{2} \mathrm{O}_{3}$ contents in 6-01 and 6-06 shows that the material is glass phase. The high $\mathrm{K}_{2} \mathrm{O}$ content seems to have been caused by charcoal or other organic materials introduced during smelting. The high $\mathrm{FeO}$ and $\mathrm{SiO}_{2}$ content in 6-02 and 6-05 indicates that the material is fayalite. 6-03 had high FeO 

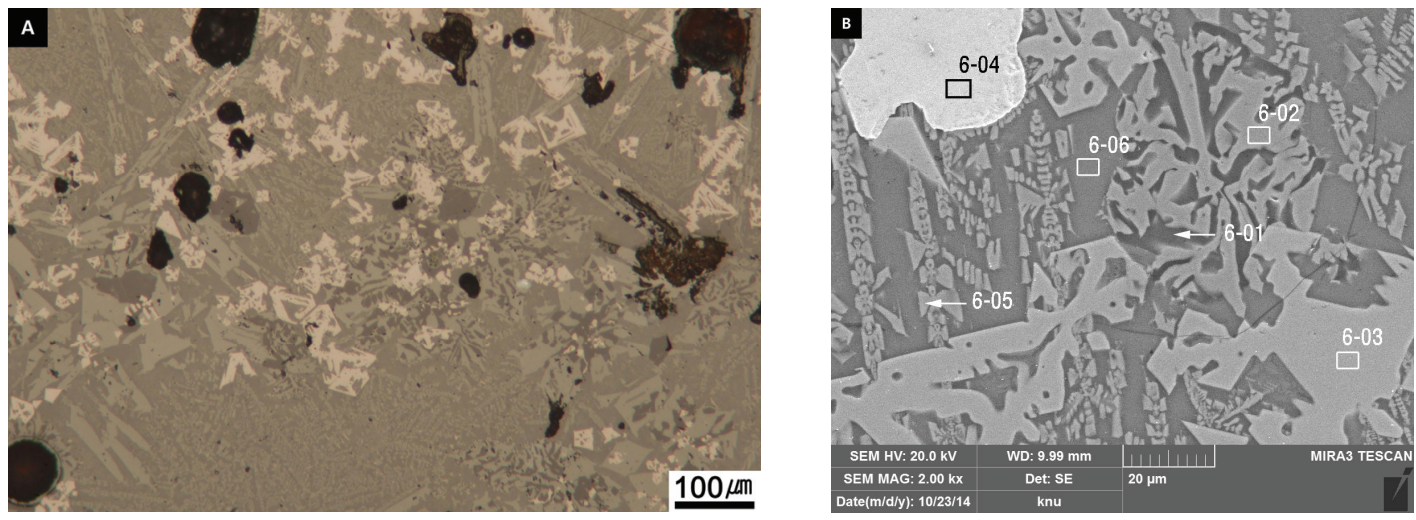

Figure 8. Microstructure of NG-6 slag; (A) Image of merallurgical microscope, (B) SEM image and point of EDS analysis.

Table 8. EDS analysis results of NG-6 slag

\begin{tabular}{ccccccccccc}
\hline \multirow{2}{*}{$\begin{array}{c}\text { Spec- } \\
\text { trum }\end{array}$} & $\mathbf{7 e O}$ & $\mathrm{TiO}_{2}$ & $\mathbf{S i O}_{2}$ & $\mathbf{C a O}$ & $\mathrm{Al}_{2} \mathbf{O}_{3}$ & $\mathbf{M g O}$ & $\mathbf{K}_{2} \mathbf{O}$ & $\mathbf{V}_{2} \mathbf{O}_{5}$ & $\mathbf{M n O}$ & $\mathbf{N a}_{2} \mathbf{O}$ \\
\hline $\mathbf{6 - 0 1}$ & 10.89 & - & 48.08 & - & 19.73 & - & 21.29 & - & - & - \\
\hline $\mathbf{6 - 0 2}$ & 59.18 & - & 29.17 & 0.95 & 3.33 & 4.49 & 1.93 & - & 0.95 & - \\
\hline $\mathbf{6 - 0 3}$ & 60.33 & 27.16 & 0.45 & - & 4.66 & 1.29 & - & 5.38 & 0.73 & - \\
\hline $\mathbf{6 - 0 4}$ & 100.00 & - & - & - & - & - & - & - & - & - \\
\hline $\mathbf{6 - 0 5}$ & 71.86 & 1.13 & 21.21 & 2.08 & - & 2.32 & - & - & 1.40 & - \\
\hline $\mathbf{6 - 0 6}$ & 27.53 & 2.88 & 38.81 & 15.23 & 12.93 & 0.38 & 1.82 & - & - & 0.43 \\
\hline
\end{tabular}

and $\mathrm{TiO}_{2}$ contents, which confirms the material as ulvöspinel. 6-04 had high $\mathrm{FeO}$ content above 99\%, which suggests that iron particles remaining in the structure after smelting may have been mixed in the slag.

\section{DISCUSSION AND CONCLUSIONS}

The following information was obtained from the analysis of the iron making by-products from the Gogi-ri site in Namwon.

An analysis of the principal components of the by-products from the site found total Fe contents ranging between $23.24 \%$ and $37.56 \%$, which is lower than the typical total $\mathrm{Fe}$ contents (30 to 50\%) in ancient smelting processes. The finding suggests a high iron recovery ratio. The deoxidation agent contents ranged from $43.88 \%$ to $58.13 \%$, which is higher than the typical deoxidation agent contents in ancient iron manufacture (17 to $40 \%$ ). The finding suggests smooth smelting operations. The high contents of $\mathrm{TiO}_{2}$ and $\mathrm{V}_{2} \mathrm{O}_{5}$ suggest the use of raw materials with high titanium content. In the past, raw materials used for smelting were estimated based on the content of $\mathrm{TiO}_{2}$ and $\mathrm{V}_{2} \mathrm{O}_{5}$. But According to a recent study by Cho et al. (2018), when low titanium sand iron was used for smelting, the content of $\mathrm{TiO}_{2}$ was averaged $0.75 \mathrm{wt} \%$. It seems that it is difficult to determine the raw material only by the content of $\mathrm{TiO}_{2}$. However, since this result is the result of analyzing a small number of samples due to the limited amount of samples, it seems that more reliable results can be derived if the number of samples analyzed through additional research is increased.

As a result of analyzing the microstructures and chemical compositions of the iron making by-products from the Gogi-ri site, NG-1 showed fine leaf-like shaped wüstite and coarse wüstite on the glass phase, along with white polygonal particles. The SEM-EDS analysis confirmed the white polygonal structure as ulvöspinel. The slag was created by smelting. In NG-2, long pillar-shaped fayalite and white polygonal and tree-shaped structures were observed on the glass phase. The SEM-EDS analysis confirmed the white polygonal and tree-shaped structures as ulvöspinel, along with iron particles that seem to have remained in the furnace 
after smelting. The findings indicate that the slag was created by smelting. As for NG-3, some hammer scales have spindle-shaped wüstite on glass phase whereas others have flat, agglomerated wüstite. Through the shape of the microstructure of the hammer scales, it is possible to estimate the nature of the work of the forging process. At the beginning of forging work, a large amount of wüstite appeared in a granular form, latter part of the forging work, granular wüstite aggregate and are observed in a non-crystallized form (Song and Woo, 2012). Therefore the NG-3 seem to contain both hammer scales created from the earlier and later stages of the forging process. As for NG-4 and NG-5, long pillar-shaped fayalite were observed on the glass phase, along with leaf-like shaped wüstite and white polygonal structures. An SEM-EDS analysis confirmed the white polygonal structure as ulvöspinel. The microstructures and chemical compositions indicate that the materials are slags created by forging. As for NG-6, long pillar-shaped fayalite and white polygonal and tree-shaped structures were observed on the glass phase, along with iron particles that remained in the furnace after smelting. The SEM-EDS analysis found glass phase with high $\mathrm{FeO}$ and $\mathrm{CaO}$ contents. The high $\mathrm{K}_{2} \mathrm{O}$ content seems to have been caused by charcoal or other organic materials introduced during smelting. The white polygonal and tree-shaped structures were confirmed as ulvöspinel, and the long pillar-shaped structures were confirmed as fayalite.

Recently, studies using Raman micro-spectroscopy as well as SEM-EDS are being conducted to determine the microstructure of slag (Park et al., 2019). In this study, crystals in the microstructure were not judged through Raman micro-spectroscopy, but when compared with the results of previous studies, it was confirmed that there was no significant difference. In the future, when samples of similar relics are secured, a more precise and accurate analysis method such as Raman micro-spectroscopy will be used together to identify crystals in the microstructure.

According to the findings, the by-products from the Gogi-ri site in Namwon, Korea indicate smooth smelting operations using materials with high titanium contents. The findings suggest that the site in Gogi-ri, Namwon, Korea used to be an facility where a full range of iron making process was carried out ranging from smelting to forging, and the ironmakers used a wide array of technologies to manufacture iron products. In this study, only slags and hammer scales were analyzed, but if the analysis of raw materials such as iron ore existing in the region is carried out together, it will be of great help in understanding the raw materials and processes of iron making in this region. We hope that such research will be conducted in the future to help you understand the iron making technology in this region.

\section{ACKNOWLEDGMENTS}

This work was supported by National Research Foundation of Korea (NRF) grants funded by the Ministry of Science and ICT (No.NRF-2016M3C1B5906955).

\section{REFERENCES}

Cho, S.M., Cho, H.K., Kwon, I.C. and Cho, N.C., 2018, Material characteristic of slags and iron bloom produced by smelting process using sand iron, Journal of Conservation Science, 34(1), 39-50. (in Korean with English abstract)

Jeonju Research Institute for Cultural Heritage, 2016, Namwon Gogi-ri Iron manufacture site. Academic series 23. (in Korean)

Lee, S.Y., 2010, Material characteristics of iron slag excavated from the forging remains in Joseon Dynasty: Focusing on Mageumgol site in Dangam-ri, Kongju, Chungnam, Sinchon site in Hanchon-ri, Goheung, Jeonnam. Master dissertation, Kongju National University, Kongju, 1. (in Korean with English abstract)

Park, S.K., Kwon, I.C., Lee, S.J., Huh, I.K. and Cho, N.C., 2019, Microstructural analysis of slags using Raman micro spectroscope, Journal of Conservation Science, 35 (2), 145-152. (in English abstract)

Rho, T.C., 2000, A historic study on the ancient merallurgical technology in Korea. Hakyounmunhwasa, Seoul, 338. (in Korean with English abstract)

Song, J.I. and Woo, K.D., 2012, Forging process technology as observed in the microstructure of a hammer scale excavated from the Naju Bogam-ri Remains, Korean Journal of Metals and Materials, 50, 599-603. (in Korean with English abstract)

Yoon, D.S., 1986, On the slag produced in early iron metallurgy. The Journal of the National Academy of Science, 25, 380-390. (in Korean with English abstract) 